\title{
Skin Squamous Cell Carcinoma or Other Skin Carcinomas pTO TNM Finding v7
}

National Cancer Institute

\section{Source}

National Cancer Institute. Skin Squamous Cell Carcinoma or Other Skin Carcinomas pTO

TNM Finding v7. NCI Thesaurus. Code C88476.

Skin squamous cell carcinoma or other skin carcinomas with no evidence of primary tumor. (from AJCC 7th Ed.) 